\title{
Biorhythmic Changes in the Development of Velocity and Power Abilities in Biathlon
}

\author{
Božena Paugschová, Jana Gereková, Jan Ondráček ${ }^{1}$
}

\author{
Faculty of Humanities, Matej Bel University, Banska Bystrica, Slovakia \\ ${ }^{1}$ Faculty of Sports Studies, Masaryk University, Brno, Czech Republic
}

\begin{abstract}
The aim of the thesis is to analyse the relationships between biorhythms and achieved biathlete's physical performance. Through the use of a pedagogical experiment the authors determined a level of kinetic abilities and shooting skills of the biathlete at the beginning and at the end of the lead time training period. By measuring method, using of the motor tests battery and SCATT shooter training system we analysed the level of her velocity abilities, power abilities and shooting skills. By processing and comparing the results the authors define the optimum time for velocity abilities development to 6 o'clock p.m., for power abilities development to 9 o'clock a.m. and for shooting training in the afternoon or evening. The results of measuring analysed in four time intervals at 9 o'clock a.m., at 12 o'clock at midday, at 3 o'clock p.m. and at 6 o'clock p.m. and thus determined the optimum time for kinetic skills development and recommend a training process in that time.
\end{abstract}

\begin{abstract}
Abstrakt
Cielom práce je analyzovat'vztahy medzi biorytmami a dosiahnutou výkonnostou biatlonistky. Pomocou pedagogického experimentu autori zistujú úroveň pohybových schopností a streleckých zručností biatlonistky na začiatku a na konci prípravného obdobia. Metódou merania, použitím testovacej batérie zvolených motorických testov a tréningového streleckého systému SCATT zistujeme úroveñ jej silových a rýchlostných schopností a streleckých zručností. Spracovaním a porovnávaním výsledkov autori u probandky stanovujú najvhodnejši čas pre rozvijanie rýchlostných schopností o 18:00 hod. večer, na rozvijanie silových schopností ráno o 9:00 hod. a pre strelecký tréning popoludňajšie resp. večerné hodiny. Výsledky meraní analyzujeme $v$ štyroch časových intervaloch o 9:00 hod., 12:00 hod., 15:00 hod. a 18:00 hod., stanovujeme najvhodnejší čas pre rozvoj vybraných pohybových schopností a navrhujeme tréningový program v tomto čase.
\end{abstract}

Key words: $\quad$ Biathlon, biorhythm, kinetic abilities, shooting performance

Klúčové slová: biatlon, biorytmus, pohybové schopnosti, strelecká výkonnost'

Grant task VEGA 1/0409/10 Biorytmy a športová výkonnost’

\section{PROBLEM}

Chronobiology is a field of science that examines biorhythms. Klerman et al. (2002) characterizes the biorhythms as cyclic repeating processes in living organisms in more or less regular intervals. They represent quantitative and qualitative changes in living organisms, which repeat and return in the same time. The cause of periodicity has internal origin, the modulation arises from external cause (Bartůňková, 2007). Klerman et al. (2002) further states that body temperature, speed of bloodstream, blood pressure, electric resistance of the skin and muscle elasticity alter in the course of a day. Human organism is regulated by working rhythms of heart and blood vessels, stomach, liver, kidneys, endocrine glands, electric phenomena in the brain and by alternation of activity and rest, sleep and waking time. It is a matter of internal biological clocks - biological rhythms (biorhythms). Biological rhythmicity has its pragmatic meaning for instance at the study of socio-pathologic phenomena, at sports training and competition, at study and its organizing, arranging, concentrating of attention etc. To understand principles and demands of biological rhythmicity throughout the day is a part of optimization of influencing on health as bio-psycho-social quality. 
In a field of sports, the term chronobiology is relatively new issue. It is known that the time is a critical factor at all biological activities and a fundamental measurement of performance at many sports. Disruption and loss of biorhythms have always serious effects on organism, on health, on kinetic and sports performance.

Day circadian rhythms are the most important from the point of view of performance. Jančoková (2000) emphasizes their importance mainly from these reasons:

- we can avoid of some mistakes at the assessment of research results,

- knowledge of individual maximum and minimum of some rhythms enables to assess the structure of maximum and minimum of performance of specific athlete what enables the timing of the attempts at individual record etc.,

- knowledge of structure, depth and stability of biorhythms enables to presuppose in advance the consequences of fast time zone changes and the time and the simplicity or the complexity of adaptation to new environment.

There is very important to find within the day the optimal training times when the athlete achieves peak performance. Many authors deal in their research with the changes in sports performance. According to their results the optimum achieves peak performance between 9 a.m. and 11 a.m.

Wimmer (2003) also agrees with the statement that biorhythms significantly affect sports performance. According to Wimmer, many individual changes have an effect on biorhythms, for example: lifestyle, behavior, stress, eating habits, overtraining, chronological age and genetic predispositions. These differences are responsible for the athlete's individual peak performance that needs to be at a high level for the peak performance. Many athletes who tend to be tired during training are experiencing that their bodies naturally want to rest. This ultimately affects their quality of psychomotor, physiological, cognitive and psycho-emotional rhythms. Therefore, this affects the athlete's potential to achieve optimal performance. Thus, training times must vary and hold at various times during the day. Many top athletes train multiple times a day for maximum recovery and training efficiency, which enables them to perform at a high level on a continual basis. An athlete's recovery time is extremely important, and sleep is necessary, although biorhythm synchronization can have the greatest influence during the waking time.

According to circadian performance, Bartůňková (2007) distinguishes between two types of individuals: "morning type" and "evening type". Evening individuals probably have longer period in their circadian rhythm, so they are not tired in the late evening. Their internal rhythm can last 25 or more hours.

Endogenous biochemical rhythm is modulated by training to biological one. It results in biorhythm synchronization of physiological functions. Švorc et al. (2008) distinguishes between external and internal desynchronization. External desynchronization means the desynchronization of endogenous biological rhythm with environmental cycle. Internal desynchronization is state when two or more before synchronizing variables in the same organism cease to show identical frequency, identical mutual relation of acrophases, and begin to show different or changeable time relations. Flight transfers (through several time zones), long-lasting stay at high altitudes or disruption of sleep by evening sporting event give rise to desynchronization at many athletes. Several hours after arrival, physical performance falls into decline. This results in the decline of neuromuscular co-ordination and muscular power, in reactive time prolongation and in faster start of tiredness. There also decrease physical performance and ability of concentration (Bartůňková, 2007).

According to Hill (2004), it is a result of discrepancy between body rhythms, which are responding to old time zone and are preserving in body biological clock, and new time zone synchronizers, for example human activities (time of eating) and light intensity. The adaptation is more difficult in case the synchronizers shorten the day and circadian rhythm and they lead to the skipping a phase. This fact explains why the traveling from the east to the west evokes worse demonstrations of zone disease (it is more difficult to practise during morning hours). Repeated synchronization (resynchronization) includes mainly adaptation of waking and sleeping times, body temperature rhythm and later the adaptation in vegetative functions. 
Proband's personal experiences support the importance of adaptability to time zone changes as well as to the stays in the mountains. Between the races of the Biathlon World Cup, there are often only weeklasting intervals, thus, during this period, it is almost impossible to adapt to time shift. As the biathlon becomes more and more popular among TV viewers, starting time of every important race is determined by television and the organizers do not take into consideration athletes' needs. Problems of adaptation to time shift in biathlon are held back and neglected.

All athletes go through crises, when their performances are under expected levels. Their biorhythms are disrupted. The following factors influence athletic performance and his/her biorhythms: emotional and mental stresses, traveling across multiple time zones, extreme environmental changes, injury and illness. In that case, athlete's biorhythms can be adjusted by synchronization. Mental imagery can be used to counterbalance mental, emotional and physical unsynchronized rhythms. This technique is used as the athlete rests and regenerates. It is a very effective method used within sports (Wimmer, 2003).

\section{AIM}

The aim of our thesis is to find out the influence of biorhythmic changes on the development of selected biathlete's kinetic abilities, and on the basis of established facts to optimize biathlete's training process during preparation period in order to increase efficiency.

\section{TASKS}

We tried to fulfill the aim of the thesis by means of following tasks:

- Find out the state of the proband's kinetic performance at selected kinetic abilities at the beginning of the research.

- Define and realize training process, which is aimed at the development of selected kinetic abilities in the period of the achievement of the best sport results.

- Find out the state of proband's kinetic performance at selected kinetic abilities at the end of the research.

- Analyze and interpret achieved results.

\section{METHODOLOGY}

Research subject is J. G. - national biathlete representative of the Slovak republic, DOB 27.11.1984, body height $170 \mathrm{~cm}$, body weight $64 \mathrm{~kg}$. She is a member of VSC Dukla Banska Bystrica. She prepares with a national team coach Ing. M. G. She began to practise biathlon when she was ten years old. Her highlights include placing two times $10^{\text {th }}$ in individual and pursuit races and placing $9^{\text {th }}$ in sprint race in Junior World Championship in Haute Maurienne, France (2003/2004); placing 5th in relay race and two times $9^{\text {th }}$ in sprint and individual races in European Championship in Novosibirsk, Russia (2004/2005). In 2006, she took part in Olympic Games in Torino, Italy. At present she is a member of national biathlete women's team and she takes part in World Cup races. But her sports training is permanently interrupted by study duties at the university; she studies English language and physical education. She did not avoid injuries, therefore she had to end the season 2008/2009 earlier. She had been in good state of health during the testing. Last days of 7-day testing, she tended to be tired.

We realized the testing at the beginning and at the end of preparation period within year training cycle in 2007/2008. Input testing took place in athletic stadium of the Faculty of Humanities, Matej Bel University in Banska Bystrica.

Testing of 30 meters running from low-starting position was realized outside on cinder-covered track, other testing took place inside in the gym of the Faculty of Humanities, Matej Bel University in Banska Bystrica. We tested during seven days from the $15^{\text {th }}$ of June 2007 to the $21^{\text {st }}$ of June 2007 at three-hour intervals. We did measure at 9 a.m., at 12 a.m., at 3 p.m. and at 6 p.m. During these seven days, the weather was calm and sunny without fluctuations and changes. At the testing, always the same person measured the time with hand-operated stopwatch. On the basis of measured results at input measurings, we determined the times when the proband J.G. achieved the best results. We worked out subsequently train- 
ing plan with the aim to improve selected kinetic abilities. During the preparation period, the proband trained according to her coach 's training plan and also she included into training process the exercises, which we suggested with the aim to develop selected abilities and to improve shooting performance. She integrated them into her training process according to the measured times. The only problem was with the fixed time of shooting training. Therefore we preferred dry shooting training, which can be applied wherever and whenever.

We realized output measurings at the end of two-month preparation from the 13th of August 2007 to the $19^{\text {th }}$ of August 2007, three months before the Summer Biathlon World Championship in Otepää, Estonia. We tested at the same conditions and in the same places. We used the same testing sets. Again we tested during seven days at three-hour intervals at 9 a.m., at 12 a.m., at 3 p.m. and at 6 p.m.. Weather condition were almost the same.

In our work we surveyed the level of power and velocity abilities and the degree, in which biorhythmic changes influence on their progress. On the basis of existing knowledge and experiences in the field of physical education and sports preparation of biathletes, we included four motorial tests in our testing battery. We tested the level of velocity abilities by means of the test the 30 meters running from low-starting position. We tested the degree of power abilities by means of three tests. Each of the tests monitored specific aim. Explosive power of lower limbs was monitored by the test standing long jump, static and endurance power of upper limbs by the test endurance in upper grip pull-up, and dynamic power of abdominal muscles by the test crunches in 30 seconds. The choice of the tests led from the methodology of the grant task VEGA 1/0409/10 Biorytmy a športová výkonnost'.

Shooting performance we tested by means of rest shooting at a professional training system SCATT. This system helps experienced shooters to improve their skills and beginners to shorten the time needed to learn basic shooting skills. The aiming trajectory, displayed on the computer screen, provides complete information on accuracy of the aiming and errors made by the shooter before and during shooting. The system operates on the principle of the communication between electronic target, in which infra-red light is placed, and the receiver, which is fixed to the barrel of the weapon. The results are transformed into the computer where they are processed by the SCATT software. This software displays the results on the target in the form of the aiming trajectory and the shot. All shooting results can be saved for further analysis. Shooting test consisted of two shooting positions: the prone position and the standing position. The proband shot from each position ten times. She concentrated mainly on accuracy, not on shooting speed. The aim was to reach at each shot the highest value at the scale from 0,0 to 10,9 points. Number 10,9 represents the highest value, the absolute center of the target. The peak achievable result was 109 points $(10 \times 10,9)$ in the prone position and also in the standing position. We shot indoor at the target from the distance of 5 meters. In the prone position the proband lay on special mat, the type used by the biathletes during the training and the race. During the testing, she was at rest. There were no other persons and no other disturbing elements.

We present arithmetic averages of achieved performances during 7 days testing period in the charts and the tables in „Results and Discussion“.

\section{RESULTS AND DISCUSSION}

Analysis of kinetic performance and shooting at the beginning and at the end of preparation period

\section{0 meters running}

In a table 1 we present arithmetic average of performances during the testing. During input testing the proband achieved the fastest time at $6 \mathrm{p} . \mathrm{m}$. and the poorest time at $3 \mathrm{p} . \mathrm{m}$. The difference between the fastest performance and the poorest one is $0,11 \mathrm{~s}$. In spite of slight differences between measured values, we have to state that the optimal time to develop accelerative speed is at 6 p.m. On the basis of these findings, the proband integrated the exercises for the velocity development into her training program at the most appropriate time. During the training camp, there was difficult to adhere strictly to our recommended 
training plan, because the second training phase ended mostly at 6 p.m., and therefore the proband could adapt slightly her training plan in order to achieve the most effective training process.

The results of input testing were affirmed during the output testing at the end of preparation period. So we could confirm the rightness of the integrating the exercises into strenuous training program. The differences between the fastest result and the poorest one were not so significant. The difference between the best result measured at 6 p.m. and the lowest result measured at 3 p.m. is $0,07 \mathrm{~s}$. The average of measured times at 12 a.m. and at 6 p.m. is almost the same. The difference $0,01 \mathrm{~s}$ is insignificant.

Table 1 Arithmetic averages of performances during input and output testing in 30 meters running (s)

\begin{tabular}{|l|c|c|c|c|}
\hline & 9 a.m. & 12 a.m. & 3 p.m. & 6 p.m. \\
\hline input testing & 5,82 & 5,84 & 5,90 & 5,79 \\
\hline standard deviation & 0,07 & 0,06 & 0,03 & 0,06 \\
\hline output testing & 5,66 & 5,64 & 5,70 & 5,63 \\
\hline standard deviation & 0,03 & 0,07 & 0,05 & 0,07 \\
\hline
\end{tabular}

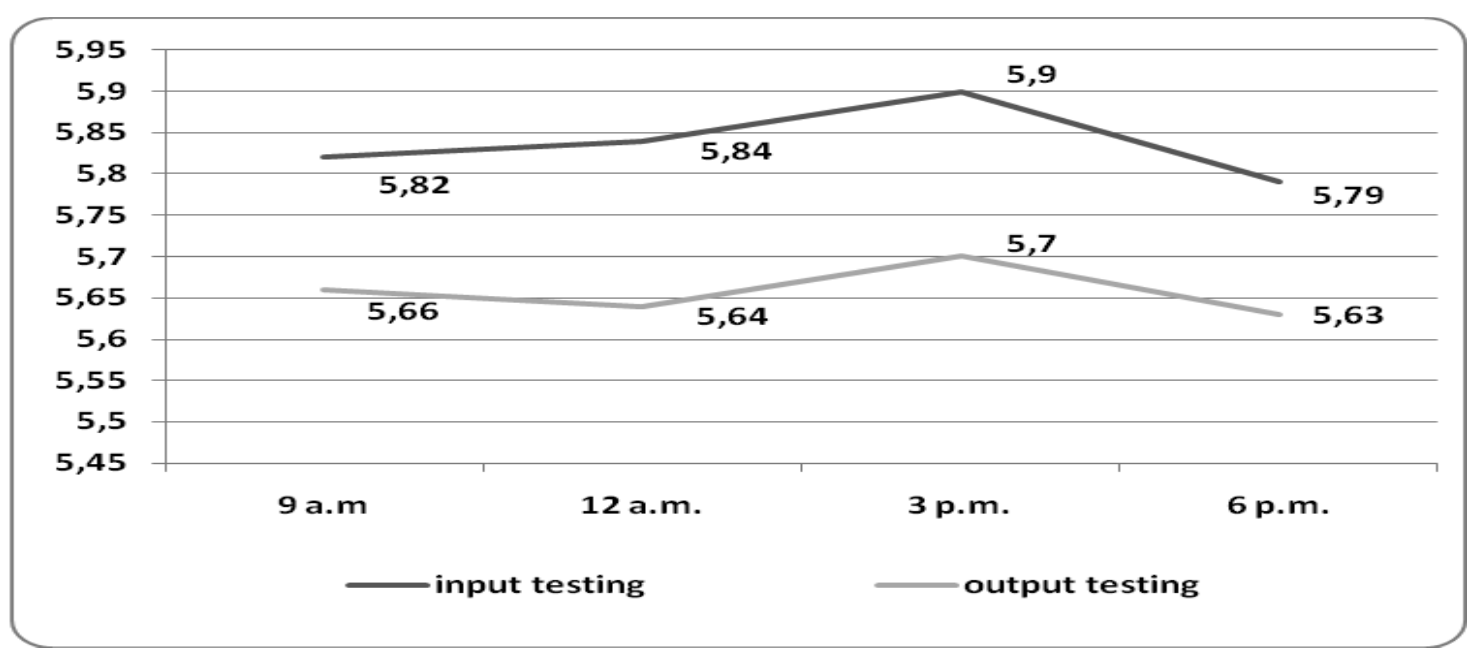

Chart 1 Graphic representation of changes in performance in the test 30 meters running (s)

\section{Standing long jump}

The results of input measurement in the table 2 affirmed that the most appropriate time for the development of explosive power of lower limbs is at 9 a.m. The least suitable time was at $12 \mathrm{a} . \mathrm{m}$. The difference between the longest attempt and the shortest one is $6,14 \mathrm{~cm}$. The proband achieved the second best result during the first testing at 3 p.m.; the result was about $2 \mathrm{~cm}$ below the average. On the basis of these findings, we worked out the training plan - the proband integrated the exercises for the development of explosive power of lower limbs into her training process.

Table 2 Arithmetic averages of performances during input and output testing in the test the standing long jump (cm)

\begin{tabular}{|l|c|c|c|c|}
\hline & 9 a.m. & 12 a.m. & 3 p.m. & 6 p.m. \\
\hline input testing & 187,57 & 181,43 & 185,57 & 182,71 \\
\hline standard deviation & 4,12 & 8,52 & 6,70 & 8,40 \\
\hline output testing & 209,14 & 204,71 & 206,29 & 208,00 \\
\hline standard deviation & 3,44 & 5,47 & 4,50 & 2,58 \\
\hline
\end{tabular}


The output testing affirmed that the most suitable time for the development of the explosiveness of lower limbs was at 9 a.m. In the evening (at 6 p.m.) the proband achieved the weaker performance by $1,14 \mathrm{~cm}$. At 9 a.m. she jumped, on average, by $4,43 \mathrm{~cm}$ more than at 12 a.m. The difference between the best jump and the worst jump was not so significant as during the first input testing.

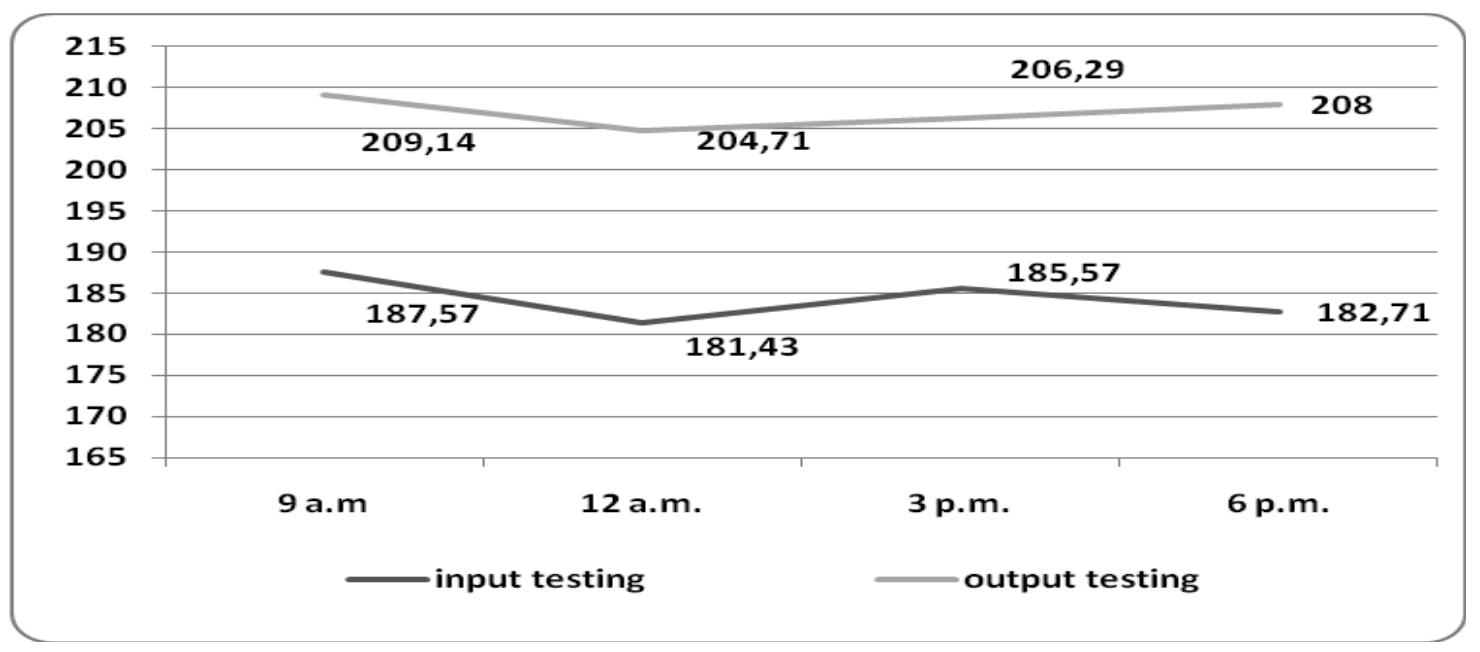

Chart 2 Graphic representation of changes in performance in the test the standing long jump (cm)

\section{Endurance in upper grip pull-up}

In the table 3, we can see arithmetic averages of proband's performances at concrete time. Input testing does not demonstrate significant differences between the performances during the day. The difference between the best result at 9 a.m. and the worst result at 6 p.m. is only 3,68 seconds. In spite of insignificant differences, we took the results into consideration and the proband integrated the exercises for the development of power abilities of upper limbs into her training program in the morning. This time was the most suitable one from the organization point of view during the training camp. She could realize these exercises in the morning during warm-up or during special warm-up before strenuous training.

Output testing showed more significant differences. The difference between the best result and the worst one is 5,87 seconds. During input testing, the least suitable time for the development of power abilities of upper limbs was during evening hours, whereas during output testing, the least suitable time was at midday. But the differences between average performances are minimal in all phases at 12 a.m., at 3 p.m. and at 6 p.m. Significant improvement is during morning hours.

Table 3 Arithmetic averages of performances during input and output testing in the test the endurance in upper grip pull-up (s)

\begin{tabular}{|l|c|c|c|c|}
\hline & 9 a.m. & 12 a.m. & 3 p.m. & 6 p.m. \\
\hline input testing & 24,78 & 23,17 & 23,20 & 21,10 \\
\hline standard deviation & 3,72 & 3,73 & 3,62 & 2,08 \\
\hline output testing & 29,40 & 23,53 & 24,33 & 23,83 \\
\hline standard deviation & 5,58 & 3,50 & 2,17 & 3,12 \\
\hline
\end{tabular}




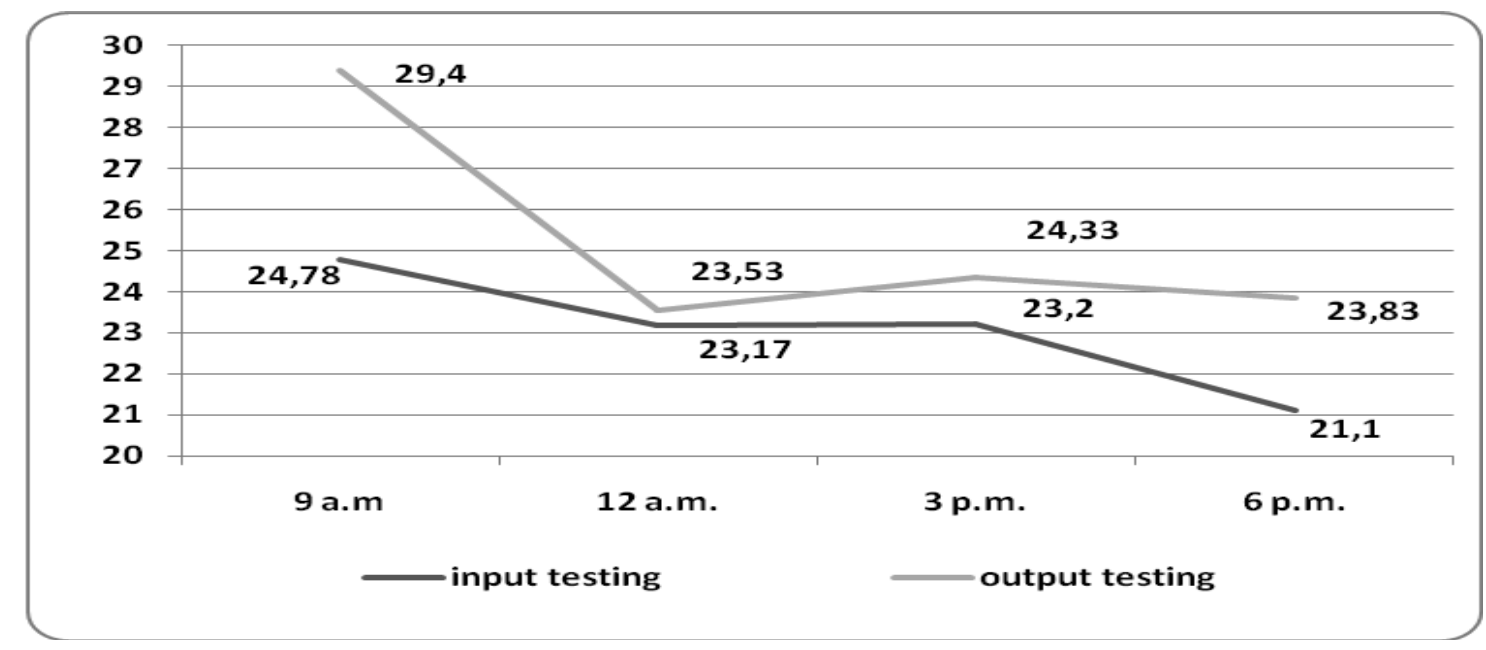

Chart 3 Graphic representation of changes in performance in the test the endurance in upper grip pullup (s)

\section{CRUNCHES}

We surveyed dynamic power of abdominal muscles by means of the crunches in 30 seconds. The result is the number of crunches in 30 seconds (table 4). During input testing, the proband achieved the best performance in the morning at 9 a.m. - 30,57 crunches on average. On the contrary, at midday she carried out only 26,43 crunches on average. This day phase was evaluated as unsuitable for the development of dynamic power of abdominal muscles. The difference between the best performance and the worst performance is 4,14 . The proband adhered to our training plan and, during the preparation period, she integrated the exercises for abdominal muscles stimulation into her training process. We determined the most suitable time to exercise at $9 \mathrm{a} . \mathrm{m}$. The proband had no problem to adhere to that time. During morning warm-up and first training phase, she did these exercises. During output testing, the results proved the appositeness of their integration into training process. The most suitable time for the development of dynamic power was at 9 a.m. The difference between measured values is not so significant as during input testing.

Table 4 Arithmetic averages of performances during input and output testing in the test the crunches

\begin{tabular}{|l|c|c|c|c|}
\hline & 9 a.m. & 12 a.m. & 3 p.m. & 6 p.m. \\
\hline input testing & 30,57 & 26,43 & 26,71 & 28,71 \\
\hline standard deviation & 2,99 & 3,55 & 2,50 & 2,42 \\
\hline output testing & 34,14 & 32,71 & 32,29 & 33,00 \\
\hline standard deviation & 1,77 & 1,38 & 0,76 & 1,00 \\
\hline
\end{tabular}




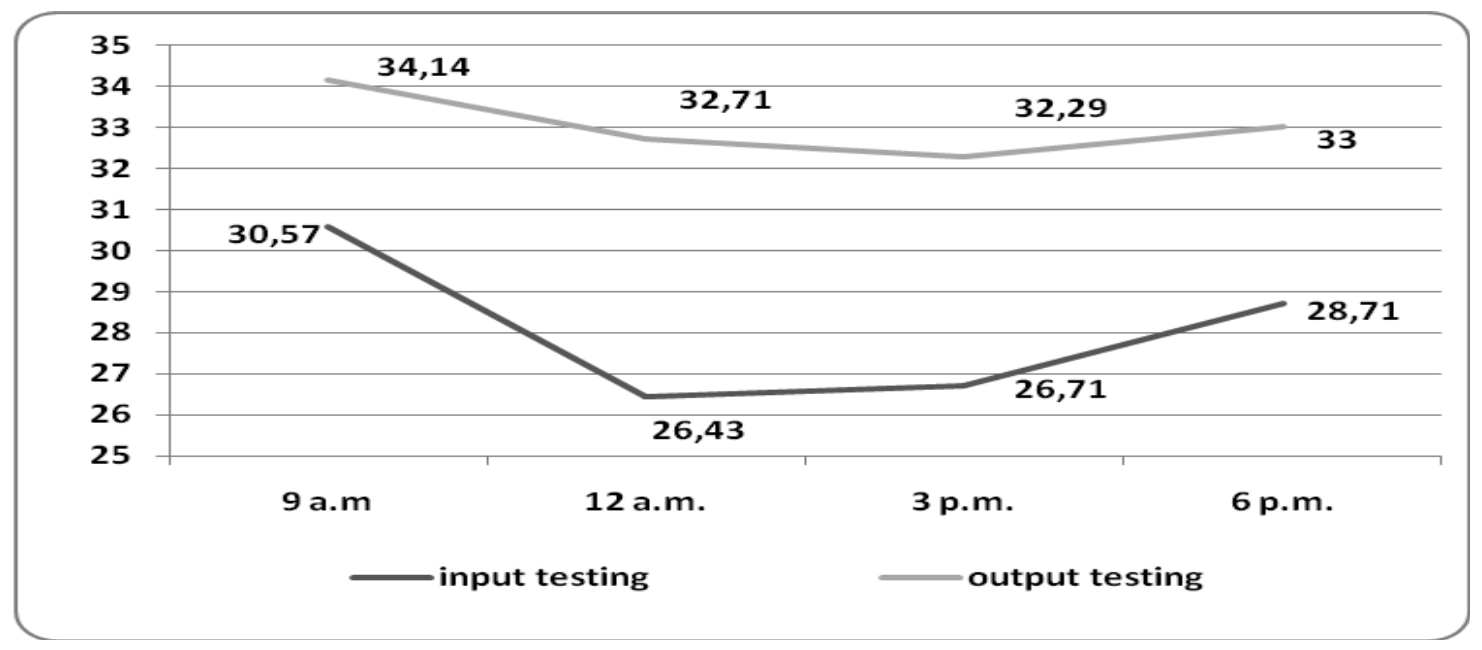

Chart 4 Graphic representation of changes in performance in the test the crunches

We evaluated the prone position shooting performance by means of electronic shooting simulator software SCATT. In the table 5 we see the results, which the proband achieved during input and output testing of rest shooting from prone position. We can see that during input testing, the proband achieved the highest score at 3 p.m. On the contrary, poorer results occurred in the morning. The difference between the best result and the worst one is 8,22 points. We can see that the differences between shooting performances in time phases are more significant as during output measuring, when the proband achieved the best result in the shooting performance from the prone position at $6 \mathrm{p} . \mathrm{m}$. The table shows that the most suitable time for the shooting training during input testing is not the same as the most suitable time during output testing. The reason for this fact is that, in spite of the determination of the most suitable time in the afternoon for the shooting training from the prone position and also from the standing position, the proband carried out complex training in the morning, during the first training phase. The first reason was the training schedule determined by proband 's coach. The proband could not change this schedule. The second reason was the fact, that we determined the most suitable time for the development of selected kinetic abilities, which are important for the biathlon, according to the results from previous testing at 9 a.m. We also lean towards the theory, that morning phase is more suitable for strenuous training (Jančoková, 2000). The stated factors prevented the proband from training of shooting at our recommended time, so we chose the alternative of dry shooting training, which is suitable and important for the improvement of shooting performance.

Table 5 Arithmetic averages of shooting performances from the prone position (points)

\begin{tabular}{|l|c|c|c|c|}
\hline & 9 a.m. & 12 a.m. & 3 p.m. & 6 p.m. \\
\hline input testing & 79,99 & 81,19 & 88,21 & 85,33 \\
\hline standard deviation & 15,95 & 10,66 & 4,75 & 3,84 \\
\hline output testing & 92,57 & 91,51 & 92,63 & 94,40 \\
\hline standard deviation & 16,75 & 10,55 & 8,15 & 16,52 \\
\hline
\end{tabular}

During preparation period, the proband integrated regularly dry shooting into her training program, mainly in the afternoon and in the late afternoon. In our opinion, this fact caused that, during output testing, the most suitable time for shooting training was at 6 p.m. 


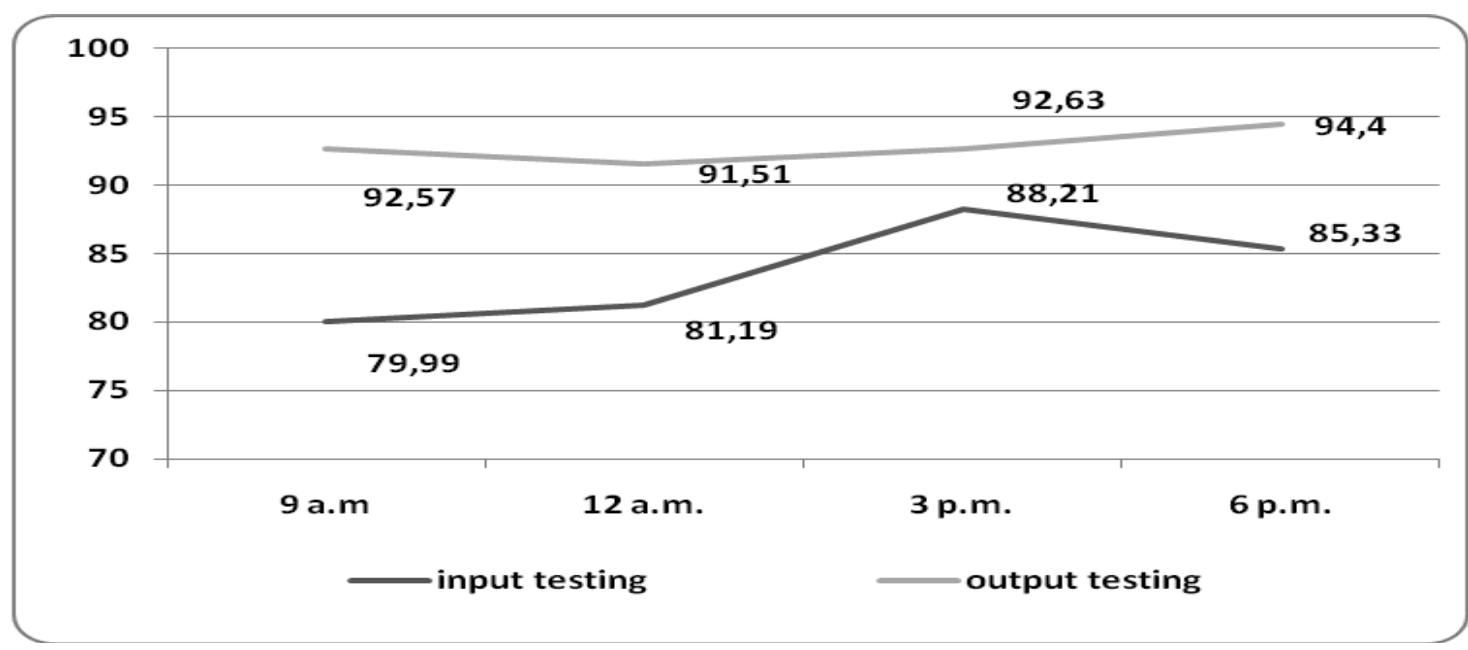

Chart 5 Graphic representation of changes in performance from the prone position (points)

We chose the similar way of the testing of shooting performances from the standing position (table 6). During input testing, we noticed considerable improvement at 6 p.m. in comparison with other phases of the day. The proband achieved the poorest performance at 12 a.m. Similarly, we integrated dry shooting for the improvement of shooting performance into proband`s training process.

During output testing, we noticed the best shooting performance at 3 p.m. and the poorest one at 9 a.m. The difference between the best performance and the worst one is 13,27 points.

Table 6 Arithmetic averages of shooting performances from the standing position (points)

\begin{tabular}{|l|c|c|c|c|}
\hline & 9 a.m. & 12 a.m. & 3 p.m. & 6 p.m. \\
\hline input testing & 47,34 & 43,64 & 46,29 & 56,71 \\
\hline standard deviation & 12,89 & 8,87 & 6,39 & 7,12 \\
\hline output testing & 46,67 & 58,53 & 59,94 & 57,61 \\
\hline standard deviation & 16,75 & 10,55 & 8,15 & 16,52 \\
\hline
\end{tabular}

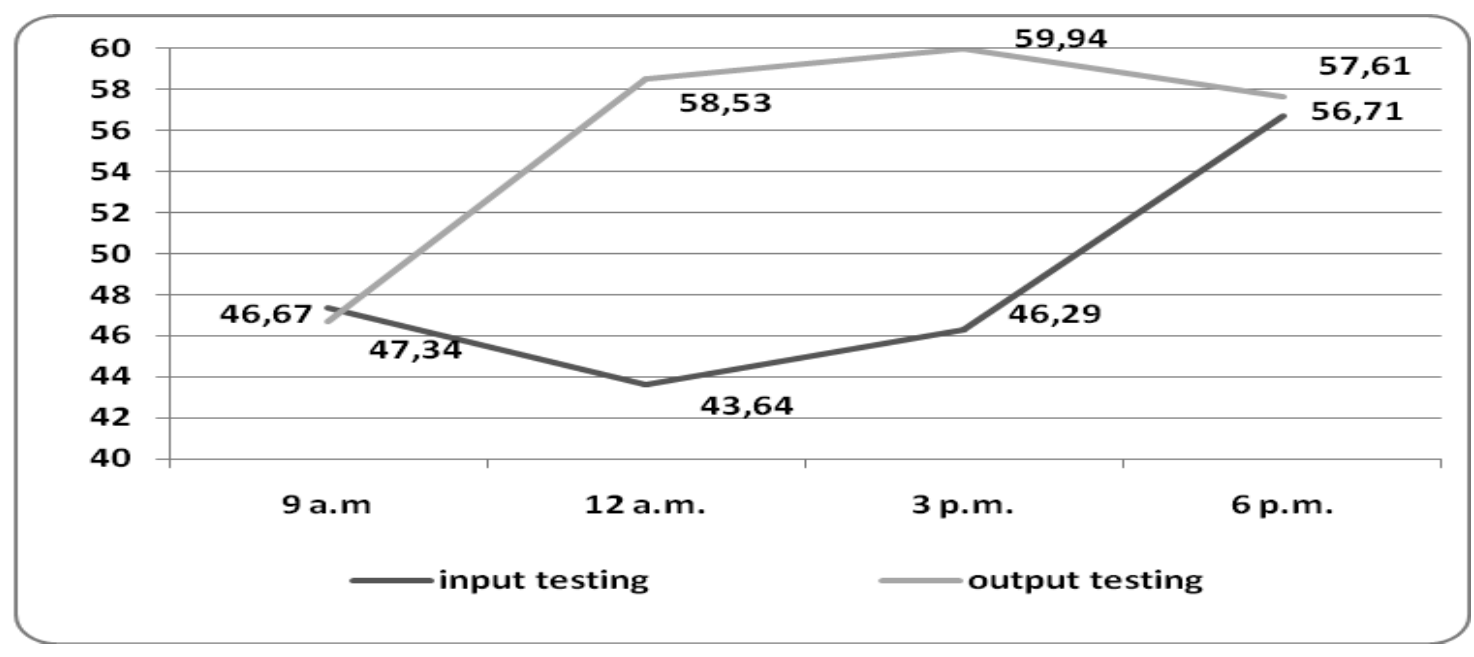

Chart 5 Graphic representation of changes in performance from the standing position (points) 


\section{CONCLUSION AND RECOMMENDATION FOR THE PRACTICE}

The aim of our thesis was to find out the extent of the influence of biorhythmic changes on the development of selected kinetic abilities. We analysed and interpreted the measured values at four motorial and two shooting tests during a period of seven days - at the beginning and at the end of preparation period.

The results of output testing confirmed the optimal time for the development of kinetic abilities, which was identical to the time from input testing. The proband 's performance during output testing improved in comparison with the performance during input testing. It means, that the improvement occurred in the development of selected kinetic abilities. At 6 p.m. (optimal time), the proband improved the 30 meters running time by $0,16 \mathrm{~s}$. She improved her long jump performance by $21,57 \mathrm{~cm}$. At 9 a.m., we recorded the improvement of upper grip pull-up (by 4,62s), and crunches (by 6,43 attempts). The results from shooting testing demonstrated optimal time at 3 p.m. and at 6 p.m. The differences between the performances were small, therefore we determined both phases of the day for the shooting training. During output testing, shooting performances from both positions improved noticeably. We affirmed statistically all results. On the basis of the results, we formulated the conclusions for sports practice:

we recommend to the proband J.G. to integrate the exercises for the development of velocity abilities into her training process in the evenings, the exercises for the development of power abilities at 9 a.m. in the mornings, and the shooting trainings in the afternoons and in the evenings. We recommend also to monitor the influence of biorhythmic changes on her performance and to adapt the greater part of the training to optimal time for the development of selected kinetic abilities. We know that everyone has own individual biorhythms. We recommend to the sports coaches to take into consideration the influence of biorhythmic changes on the performance of all athletes, and to adapt the training process to this fact.

\section{BIBLIOGRAPHY}

BARTU゚ŇKOVÁ, S. 2007. Fyziologie člověka a tělesných cvičení. Praha: Univerzita Karlova, Nakladatelství Karolinum, 2007. 285 s. ISBN 978-80-246-1171-6.

HILL, G. 2004. Moderní psychologie. Praha: Portál, 2004. 283 s. ISBN 80-7178-641-1.

JANČOKOVÁ, L. 2000. Biorytmy v športe. Banská Bystrica: UMB FHV, 2000. 120 s. ISBN 80-8055-395.

KLERMAN et al. 2002. Comparisons of the Variability of Three Markers of the Human Circadian Pacemaker. In: Journal of Biological Rhythms, 2002, Vol. 17, No. 2., s. 181-193.

KOBELA, P., PAUGSCHOVÁ, B., ŠTULRAJTER, V. 2006. Vplyv optimálnej tréningovej metódy v príprave mladých biatlonistov v závislosti na dížke a mieste pobytu v stredohorí. In: Čillík et al. Adaptácia na zataženie $v$ priebehu ročného tréningového cyklu u reprezentantov v atletike a biatlone. Banská Bystrica: FHV UMB, 2006. ISBN 80-8083-315-X, s. 80-108.

KORČOK, P., PUPIŠ, M. 2006. V̌̌etko o chôdzi. Banská Bystrica: UMB FHV, 2006. 236 s. ISBN 80-8083-185-8.

ŠTULRAJTER, V., PERÁČEK, P., HOLIENKA, M. 2005. Ako sa dá urýchlovat’ adaptácia športovcov na rozdielne časové pásma. In: Telesná výchova a šport, 2005, Vol. 15, No. 3-4. ISSN 1335-2245, s. 27-32. ŠVORC, P. et al. 2008. Chronobiológia a praktická medicína. In: Československá fyziologie [online]. 2008, Vol. 57, No. 1., s. 4-9. [cit. 2009-02-22],

Dostupné na internete:

< http://195.250.138.169/fyziologie/documents/Chronobiologia.pdf>

WIMMER, R. 2003. Using Eastern Philosophy to Optimize Sports Performance, in "Western" Terms. In: Acupuncture Today [online]. 2003, Vol. 04, No. 1. [cit. 2009-02-26]. Dostupné na internete:

http://www.acupuncturetoday.com/mpacms/at/article.php?id=28136 